\title{
Faculty status in South Carolina
}

\author{
By Sherman E. Pyatt \\ Serials/Government Documents Librarian \\ The Citadel
}

\author{
Josephine B. Williamson \\ Senior Assistant Librarian \\ University of Delaware
}

\section{and Edgar Williamson}

Assistant Librarian

University of Delaware

\section{A survey of academic librarians measures their attitudes toward faculty status.}

$\mathbf{T}$ here has been an ongoing debate in librarianship as to whether or not librarians should have faculty status and/or tenure, with the concomitant responsibilities to conduct research and publish. A variety of studies have been conducted related to this topic. ${ }^{1}$ Nowhere has the debate been hotter than in South Carolina. In the past five years, faculty status has been lost or compromised at several institutions. (One respondent stated that "our institution did away with tenure for librarians ... without consulting the librarians.") Many other institutions are threatening to follow suit. However, little has been done to solicit the attitudes of South Carolina's academic librarians about these issues. Specifically, what are their feelings about tenure and publishing? How do they think they are perceived by their colleagues in academe, the teaching faculty?

The primary purpose of this survey was to garner information on the attitudes of our colleagues

${ }^{1}$ For an excellent survey and summary of the literature see Kee DeBoer and Wendy Culotta, "The Academic Librarian and Faculty Status in the 1980s: A Survey of the Literature," College \& Research Libraries 48 (May 1987): 215-23. about their status on their respective campuses. Also, we wanted to allow them a chance to express their feelings about their relationship with the teaching faculty and administrators with whom they work. Finally, a profile of the "typical" academic librarian in the state was to be constructed.

\section{Methodology}

Questionnaires were mailed to 229 librarians at accredited institutions of higher education in South Carolina. We chose to survey all academic librarians in the state because the small size of the group made sampling unnecessary. The names of librarians at smaller institutions were obtained from the American Library Directory, 40th edition. The four largest institutions were contacted by phone for the names and mailing addresses of all of the librarians on their staffs. All were very cooperative and provided the information promptly. Usable responses were received from 155 librarians, vielding a response rate of $67.7 \%$. The respondents included librarians from all four-year colleges, universities, and graduate/professional schools in the state of South Carolina. Two-year colleges and technical schools were not polled because librarians at these institutions do not have and are not 


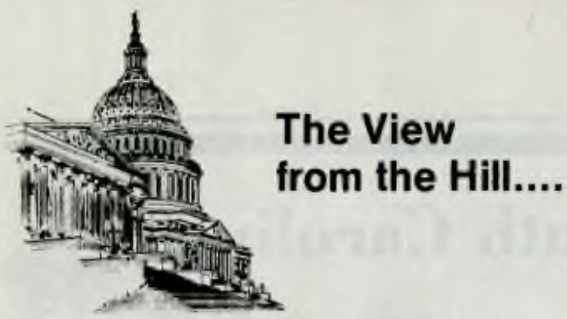

The General Accounting Office was established in 1921, "independent of the executive departments" to keep track of whether or not, and if so how, the executive branch carried out the programs and laws enacted by Congress.

"The rest," as they say, "...is History."... and Political Science,.... and Sociology,.... and Law,.... and Economics,... and Business,.... and Consumer Affairs,... and International Studies,... and Military and Space Sciences,... plus almost every other academic program included in postsecondary curricula.

GAO's mission, modified by numerous statutes since its founding, has grown in size and complexity along with the Federal Government itself. By 1987 GAO had a staff of over 5,100 and an annual budget of $\$ 300$ million....by any standards one of the largest information gathering organizations in the world.

During the last 14 years, GAO's multidisciplinary staff has produced a total of some 40,000 documents, 13,739 of which were full reports and testimonies (not counting decisions, opinions, speeches and other documents). Only 5,316 of these GAO documents of all types were distributed by The Government Printing Office. For 1987, GAO published 767 reports and 167 testimonies and only 61 GAO publications of all types were processed through GPO.

As the GPO Monthly Catalog and its computer tapes are the sources for online bibliographic "government documents" databases and $\mathrm{CD} / \mathrm{ROM}$ indexes as well as for the distribution of microfiche copies of depository and nondepository items, it is clear that in-house access to the bulk of this important collection covering the full range of U.S. Government activity - has never before been made available to academic libraries.

\section{Integrated Indexing}

The main entries contain full bibliographic citations plus complete abstracts. Eleven separate indexes allow searching by such fields as title, subject, organization. personal name, and law/authority, as well as a massive keyword index to significant terms in both the citations and abstracts.

The keyword indexing of the CD/ROM Edition is greatly expanded to allow Boolean searching of the full text of the abstracts.

\section{A New Perspective On' Vital National Issue}

G.A.O

$G_{A O}$
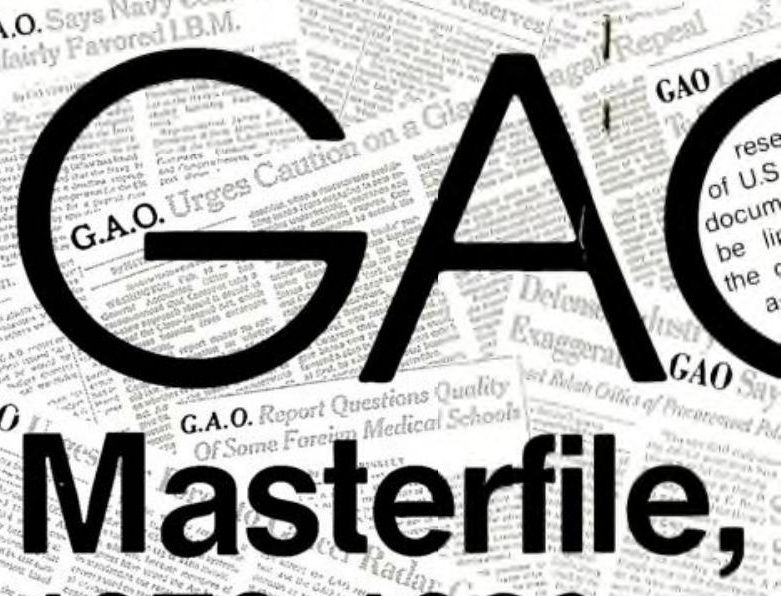

1976-1989

GA0

The Documents Behind the

This self-contained reference set gives res access to information on all aspects of U.S. G operations and interests.

Out of the tens of thousands of GAO docun abstracts that are indexed in the Masterfile, le been distributed by the Government Printing

The complete GAO Masterfile System inclu

- in-depth access to every public docume over the last 14 years,

- your choice of index formats - one CD hardcover volumes.

GAO

- microfiche sets containing the full text c documents,

- SuDocs Numbers added to non-GPO ite into documents collections,

- document delivery of print copies,

G.A.O

- an "800 Number" Reference Hotline, an

- cumulative annual updating for the CD/ Annual Supplements for the print versio 


\section{...}

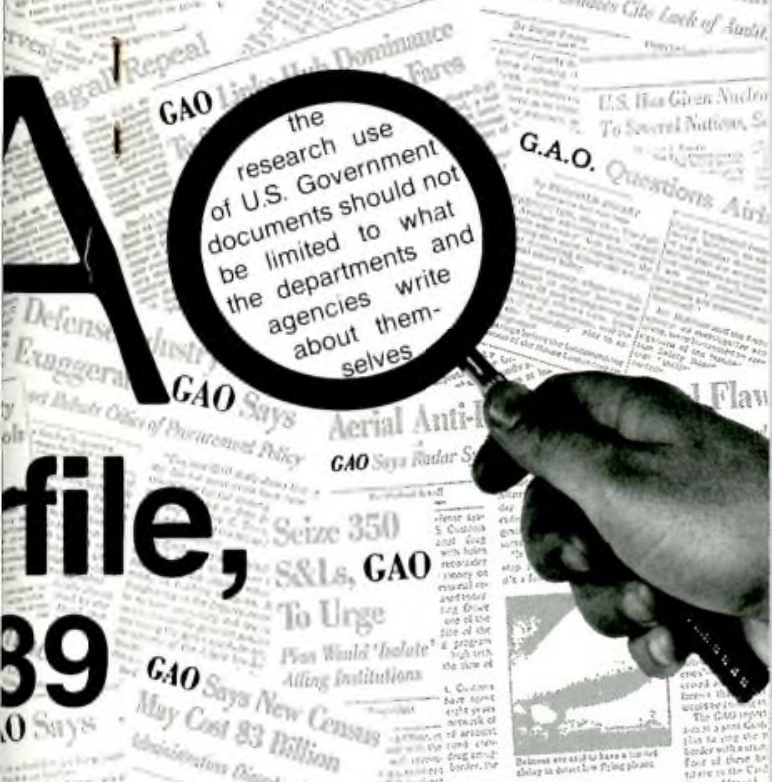

\section{Behind the Headlines}

rence set gives researchers newfound all aspects of U.S. Government

ands of GAO documents, citations and in the Masterfile, less than $15 \%$ have overnment Printing Office.

sterfile System includes

every public document produced by GAO s,

formats - one CD/ROM disc or fifteen

I

aining the full text of indexed

ded to non-GPO items for integration ections,

f print copies,

eference Hotline, and

pdating for the CD/ROM Edition and $s$ for the print version.

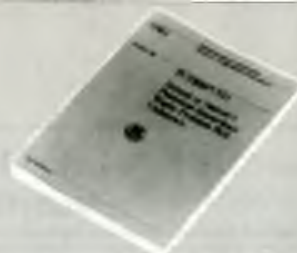

The

Documents

The following sample titles are typical of the recent reports contained in the GAO Masterfile which have not been listed in the Monthly Catalog.

- AIDS Forecasting: Undercount of Cases and Lack of Key Data Weaken Existing Estimates, June 1989. $102 p$.

- Biotechnology: Managing the Risks of Field Testing Genetically Engineered Organisms, June 1988, 108p.

- Drug Smuggling: Capabilities for Interdicting Private Aircraft Are Limited and Costly, June 1989.

- Energy Security: Analysis of Studies on Economic Consequences of an Oil Import Tarifi, June 1989, $74 \mathrm{p}$.

- Health Care: Home Care Experiences of Families with Chronically III Children, Human Resources Division, June 1989, 51p.

- Homelessness: Implementation of Food and Shelter Programs Under the McKinney Act, December 1987, 40p.

- Immigration Control: A New Role for the Social Security Card, March 1988, 62p.

- Impacts of Education Reform, March 89, 24p.

- Indian Affairs: Statistical Data on Indian Rights Cases Handled by Justice, April 1988, 8p.

- 1990 Census: Overview of Key Issues, July 1989. $32 p$.

- Nuclear Power Safety: International Measures in Response to Chernobyl Accident, April 1988, 38p

- Seafood Safety: Seriousness of Problems and Efforts to Protect Consumers, August 1988, 77p.

- Strategic Bombers: Logistics Decisions Impede B1B Readiness and Supportability, May 1989.

sed, G.A.O. - Strategic Defense Initiative Program: Information on Reprogramming and Department of Energy Efforts, May 1988.

- Sweatshops in the U.S.: Opinions on Their Extent and Possible Enforcement Options, August 1988.

- U.S.-Japan Burden Sharing: Japan has Increased its Contributions but Could Do More, August 1989 , $54 p$.

Write for detailed brochure or call 1-800-752-0515

\section{Pre-Publication Prices} (through Dec. 31. 1989)

Indexes

口 15 Volume Set, \$2,250, (1990 Supplement, \$325)

口 CD/ROM Disc, \$1,950, (1990 Cumulation, \$1,950)

$\square$ Combination (CD at $1 / 2$ price) $\$ 3,325$

Microfiche

口 \$2,900 per year

Also available by type of report and GAO division. 
TABLE 1

PUBLISHING RECORD

Workpublished

Respondents $(\mathrm{N}=155)$

Number

Percent

Book 9

Article in national joumal

27

$5.8 \%$

Article in regional journal

12

$17.4 \%$

Article in state journal

$7.7 \%$

Other

$10.3 \%$

None

eligible for faculty rank or status.

The questionnaire was designed to measure the attitudes of librarians, regardless of rank, toward their status at their respective institutions. Professional and personal characteristics were also solicited. Other surveys of this type have queried only head librarians/directors ${ }^{2}$ or university administrators $^{3}$. We chose, instead, to survey all academic

${ }^{2}$ See Greg W. Byerly, "The Faculty Status of Academic Librarians in Ohio," College \& Research Libraries 41 (September 1980): 422-29; Marjorie A. Benedict, Jacquelyn A. Gavryck, and Hanan C. Selvin, "Status of Academic Librarians in New York State," College \& Research Libraries 44 (January 1983): 12-19; Becky Bolte Gray and Rosalee McReynolds, "A Comparison of Academic Librarians with and without Faculty Status in the Southeast," College \& Research Libraries 44 (July 1983): 283-87.

${ }^{3}$ See Thomas G. English, "Librarian Status in the Eighty-Nine U.S. Academic Institutions of the Association of Research Libraries: 1982," College \& Research Libraries 44 (May 1983): 199-211. librarians in the state because we agree that "their views are frequently at variance with those of their directors." We also felt that this would give us a more accurate reflection of the "typical" academic librarian's perceptions and feelings.

That this is a "hot" topic in South Carolina we have no doubt. The strength of feeling surrounding this subject is partly evidenced by the fact that $50 \%$ of the questionnaires were completed and returned within ten days. (It should be stressed that questionnaires were sent out in August, a time of vacation for many librarians!) Also, the attitudinal portion of the survey contained a very low rate of "don't know" responses. For all ten statements the highest percentage of such responses was only $16.7 \%$.

${ }^{4}$ Russ Davidson, Connie Capers Thorson, and Diane Stine, "Faculty Status for Librarians: Querying the Troops," College \& Research Libraries 44 (November 1983): 414-20.

TABLE 2

PUBLISHING RECORD BY GENDER

\begin{tabular}{lrrrrr}
\hline \hline Work published & Male & \multicolumn{1}{c}{$(\%)$} & Female & $(\%)$ \\
\hline Book & 6 & $9.7 \%$ & 3 & $3.2 \%$ \\
Article in national journal & 17 & $27.4 \%$ & & 10 & $10.8 \%$ \\
Article in regional journal & 3 & $4.8 \%$ & 9 & $9.7 \%$ \\
Article in state journal & 9 & $14.5 \%$ & 7 & $7.5 \%$ \\
Other & 8 & $12.9 \%$ & & 17 & $18.3 \%$ \\
None & 19 & $30.6 \%$ & & 47 & $50.5 \%$ \\
\cline { 2 - 6 } & 62 & $99.9 \%$ & & 73 & $100.0 \%$ \\
\hline
\end{tabular}




\section{Profile}

A review of the responses presents the following profile of the "typical" South Carolina academic librarian. This librarian would:

- be a female $(60.0 \%)$ who has been a librarian between 11 and 20 years $(46.1 \%)$;

- have faculty status $(92.8 \%)$ and rank $(40.7 \%)$, be eligible for tenure $(83.0 \%)$, but not have tenure $(54.6 \%)$;

- have published something (57.4\%), most likely an article in a national journal $(17.4 \%)$;

- work in a university library $(51.0 \%)$ containing between 100,001 and 500,000 volumes $(60.4 \%)$ with a staff of 5 to 10 professionals (42.6\%);

- have an official work week of between 35 and 39 hours $(83.7 \%)$, a twelve-month contract $(96.7 \%)$, and fewer than 20 days vacation per year $(46.1 \%)$;

- not have a written personnel policy specifically for librarians $(72.4 \%)$, but have an institutional grievance board $(78.7 \%)$; and

- receive a salary less than the teaching faculty $(64.7 \%)$.

It is interesting to note that, of those eligible for tenure, only $34.6 \%$ said that they are required to publish or do research to achieve tenure. This could be due in part to the presence of tenured librarians who achieved tenure before publishing and/or research were required. For example, of those tenured, $24.3 \%$ stated that they have published nothing. It is also clear that publishing and or research are not officially encouraged at most institutions, since only $20.5 \%$ said they receive release time to do so. On the other hand, a few respondents said that no one had ever actually asked for it. In addition, the percentage forced to use annual leave for research trips is equal to those who are not $(41.0 \%)$.

When asked, "Do librarians at your institution receive salaries comparable to those of the teaching faculty?" the majority (73.8\%) answered no. One comment reflects the thoughts of many: "librarians receive 'equal' salaries to other faculty of equal rank except librarians must work nights, weekends, holidays and 12 months for what faculty receive in 9 months with no nights or weekends, and all normal class holidays (i.e., semester and mid-term breaks, and other holidays)." Another librarian commented that "librarians receive comparable annual salary as teaching faculty, but must work 12 months for it instead of 9 months." This respondent also mentioned that librarians usually work during periods when the school is otherwise closed, such as Christmas and Spring breaks, snow days, etc.

\section{Publishing}

As described above, most of the librarians sur- veyed have published something (57.4\%). However, if the item published is limited to books and articles, the number who have published drops to $41.2 \%$ (see Table 1). Many who marked "other" after this question indicated that they regard inhouse bibliographies, pathfinders, indexes to books, college journals, etc., as published works. It may be argued that these should not be counted as such. Therefore, it may be more accurate to say that the typical academic librarian in South Carolina has not published anything in the usual academic sense of the word.

As might be expected, most tenured librarians have published something (75.7\%), while most untenured librarians have not $(57.1 \%)$. In addition, all nine of the librarians who have published a book are tenured. If "other" publications are excluded, the balance is even more heavily in favor of tenured librarians, with $61.4 \%$ of them having published a book or article compared to $25.0 \%$ for untenured librarians. Of those untenured librarians eligible for tenure, $41.7 \%$ have published something. It seems clear that they are responding to the pressure to publish.

The survey shows that academic librarians in South Carolina mirror the nationwide trend of men publishing at greater rates than women. ${ }^{5}$ Less than half of the female respondents have published something. whereas nearly $70 \%$ of the males have done so (see Table 2). To test the significance of sex and publishing, a $2 \times 2$ chi-square test was constructed. It was found that the calculated chisquare value (6.02) is significant at the .05 level ( $X$ $=3.84$ with $\mathrm{df}=\mathrm{l}$ ). This supports the hypothesis that sex influences the likelihood of publishing.

\section{Attitudes}

In Part III of the survey, respondents were asked to indicate their attitudes toward ten statements by marking whether they "strongly disagree, disagree, don't know, agree, or strongly agree." The first statement was, "Teaching faculty at my institution treat librarians as colleagues who have the same rights, privileges, and responsibilities as they do." Negative attitudes nearly balance positive ones, with $42.2 \%$ of all respondents disagreeing and/or strongly disagreeing with this statement and $49.4 \%$ agreeing and/or strongly agreeing. It is noteworthy to compare these answers with those given for the last statement: "Overall, librarians at my institution enjoy equal status with the teaching faculty." In this

${ }^{5}$ See Martha C. Adamson and Gloria J. Zamora "Publishing in Library Science Journals: A Test of the Olsgaard Profile," $C \& R L 42$ (May 1981): 23541; John N. Olsgaard and Jane Kinch Olsgaard, "Authorship Characteristics in Five Library Periodicals," CoRL 41 (January 1980): 49-53. 
case, negative feelings outweigh the positive ones, with $50.3 \%$ disagreeing or strongly disagreeing with the statement and $43.8 \%$ agreeing or strongly agreeing. The differences may be accounted for by the fact that the second statement encompasses the esteem a respondent receives not only from the faculty, but also from the administration.

The second statement dealt with annual leave: "Annual leave for librarians at my institution is adequate." Most (58.8\%) agree or strongly agree with this statement. Only $38.0 \%$ do not.

The results discussed thus far seem to indicate that, on average, academic librarians in South Carolina seem to feel fairly satisfied with their current work environments. This positive set of feelings is reflected in their responses to the sixth statement: "If I had it to do over again, I would not become an academic librarian." Only $16.0 \%$ of the respondents say they agree and/or strongly agree. Fully $67.3 \%$ disagree and/or strongly disagree. In other words, nearly two-thirds would do it again. It is interesting to note that this statement elicited the largest percentage (16.7\%) of don't know answers of all ten of the attitudinal statements.

Several statements were presented to elicit attitudes with respect to tenure. One statement said, "Librarians should be eligible for tenure." People overwhelmingly agree and/or strongly agree with this by nearly a seven to one margin (119 versus 18 , with only 15 marking "don't know"). However, when confronted with the statement, "Librarians should be required to publish for tenure and/or promotion," $56.0 \%$ disagree and/or strongly disagree. Twelve percent say they don't know and only $32.0 \%$ agree and/or strongly agree.

There appears to be even stronger feeling against the idea of using the same criteria for tenure as the faculty uses. Sixty-six (66.4) percent disagree and/or strongly disagree with the statement, "Librarians should be judged by the same criteria as teaching faculty for tenure and/or promotion." It seems clear that academic librarians want to be eligible for tenure, but not on the same basis as the teaching faculty. One respondent put it succinctly, stating that "librarians should not be expected to publish or perish on a 12-month contract." Another commented that "librarians should not be forced into 'pretending' that they are the same and/or 'equal' to teaching faculty. and they should not be forced into trying to mold their duties into 'categories' that correlate to teaching faculty duties."

On the other hand, many respondents argued that librarians should work toward establishing unique criteria which reflect "the vastly different responsibilities" of librarians as compared to the teaching faculty. Adding a criterion such as "professional involvement to [the] research and publication category" and allowing activities such as "internal studies and presentations at meetings to substitute for formal publications" were offered as solutions to the problem. Another suggestion is to define publication "loosely for purposes of tenure, [to] include in-house bibliographies, manuscripts in preparation, etc." Another respondent proposed that librarians "be judged by criteria that similarly parallel their job duties [such as] 'competence as a librarian' in place of 'teaching effectiveness." One librarian expressed some skepticism as to whether this would work: "We could develop our own criteria . . but that won't necessarily guarantee acceptance by the rest of the academic community."

Three statements were included as part of the survey in order to ascertain what librarians might like to alter about their working conditions. The most popular change would be to allow librarians to have sabbaticals: $90.9 \%$ agree and/or strongly agree with this (in fact, this statement had the highest percentage $(53.2 \%$ ) of strongly agree answers). Another popular change would be to get rid of the forty-hour work week. Only $23.7 \%$ agree and/or strongly agree that "Librarians should work a 40-hour work week." Finally, most (57.1\%) agree and/or strongly agree that "Librarians should be given the option of a 9 or 12 month contract." The strength of feeling about this issue may be a reflection of the pressure academic librarians experience when they must do research and/orpublish with no time off to do so (see comment above). It would be interesting to see whether or not this feeling subsided if librarians were not required to do these activities to be tenured/promoted.

\section{Conclusion}

The most striking finding of this survey is the degree of agreement among South Carolina's academic librarians. This holds true for both tenured and untenured librarians alike. They want sabbaticals, variable-length contracts, and faculty status. They do not want to be held to a 40 -hour work week. They want to be eligible for tenure, but they want to be judged by criteria which reflect the duties and responsibilities of librarians, not those of the teaching faculty. Many respondents provided excellent alternatives for these criteria. It is hoped that some of these suggestions will be implemented. More research needs to be done regarding institutions which have done so successfully.

There is some discord among respondents. On the subject of faculty status, one person commented that "if librarians spent less time whining about faculty status and more time doing real scholarship, we might get more respect." Of course, this comment begs the question of how much real administration support exists for doing so. Perhaps with sabbaticals and paid research leave, more "real scholarship" would be produced. Librarians are split rather evenly over the question of being 
treated as colleagues by the faculty. The same is true with respect to their feeling that they have equal status on campus.

Further research needs to be done with respect to attitudes concerning tenure, faculty status, and equality of treatment. For example, it would be interesting to know if there are any differences in attitudes between male and female librarians, tenured and untenured librarians, directors and other librarians, to name a few. One librarian commented: "I have sometimes entertained the nasty thought that faculty rank and status for librarians is a device promoted by reference and public service librarians who seek to be taken seriously and professionally by an elitist and condescending teaching faculty." This illustrates alienation, not only from the rest of the faculty, but also from other librarians. Additional study should be made to determine if this comment reflects the general attitude of technical service librarians. If true, it may indicate that we librarians need to reconcile our own differences before expecting much faculty support for granting us the privilege of tenure and faculty status.

\section{年 News from the Field}

\section{Acquisitions}

- The University of Virginia's Alderman Library, Charlottesville, recently acquired an original 1805 letter written by Thomas Jefferson to his friend Philip Mazzei, an Italian wine merchant, requesting that he send two bottles of wine from Europe to the White House. Currently, Alderman Library owns approximately 2,500 original Jefferson letters. The Mazzei letter, the most recent edition to the collection, was purchased this summer from the Daniel F. Kelleher Co. Inc., auction house in Boston. The purchase was funded by the Monticello Memorial Foundation, which has financed the buying of original Jefferson writings for Alderman Library for the past 22 years. Currently housed in a climate-controlled vault on the second floor of Alderman Library, the letter is one sheet of paper, handwritten.

- Villanova University, Villanova. Pennsylvania, has received from the University of Würzburg a machine-readable concordance to the critical Latin editions of the works of St. Augustine. The concordance was developed through the efforts of Professor Cornelius Mayer, O.S.A. Villanova is the only U.S. site for this resource.

\section{Grants}

- The Brandeis University Libraries, Waltham, Massachusetts, in conjunction with the Lemberg Program in International Economics and Finance, has received a $\$ 24,000$ gift from the Consulate General of Japan, Boston. The gift will be used to purchase books and serials on Japanese economics, as well as fine arts, literature, and Japanese culture and history. Areas of particular interest to Brandeis's Department of. Economics are Japanese labor markets, U.S.-Japan trade, and U.S.-Japan economic relations. These materials will be used as a foundation to promote better understanding of Japanese life and strengthen interest on campus in Japanese studies.

- The Center for Research Libraries. Chicago, has received a bibliographic access grant of $\$ 236,331$ from the U.S. Department of Education under the Higher Education Act Title II-C Strengthening Library Resources Program. This award will enable retrospective conversion of 56,000 Roman-alphabet records for monographs in the center's card catalog. The Department of Education approved a three-year project period for the retrospective conversion project and funded a one-year period beginning October 1 , 1989. The federal funds are financing all of the project costs. In the current, final phase of retrospective conversion, the center is treating 240,000 monographic records. This represents approximately 160,00 records in Roman alphabet for materials in original format, 35,000 records in cyrillic alphabet, 40,000 records for microforms, and 5,000 records with main entry, collation, etc., problems that must be solved by consulting the materials. This grant will move the center significantly forward toward a completely machine-readable catalog and will improve researchers' online access to its infrequently-held resources.

- Emporia State University Kansas, has recieved a $\$ 28,145$ grant from the National Endowment for the Humanities to support lectures, 